\title{
COMMENTARY ON PAPERS PRESENTED AT THE 1991 SEMINAR
}

\section{CONSTANCE D. HUNT*}

The papers presented at the Canadian Petroleum Law Foundation's Thirtieth Annual Research Seminar in Oil and Gas illustrate the fact that petroleum lawyers continue to be challenged both by familiar issues whose context, in some cases, has changed over the years, and by new issues that are reflective of current economic and social circumstances. The purpose of this short commentary is to provide an overview of some of the themes that emerge from this year's papers and to suggest a number of matters that are likely to require increasing attention by petroleum lawyers in the last decade of this century.

It is hardly surprising, in 1991, that environmental and related issues are addressed, in some fashion or another, in several of the papers. Miller and McFarlane's paper underscores the fact that we are in a period of considerable change in this regard; the resulting uncertainty means that lawyers must take a broad view of the emerging issues, keep abreast of developments from other jurisdictions (which may reveal important trends), and be as creative as possible in advising their clients and devising solutions to new problems. The authors make the important observation that the acceptance of risk has always been a fundamental part of carrying on business; rather than walking away from deals because of the uncertainty surrounding environmental issues, the business community should be prepared to learn from risk allocation techniques that have been commonly and successfully employed in other circumstances. They have provided an outline of procedures to be followed in relation to acquisitions and divestitures, taking environmental concerns into account; while it is helpful to have such a framework as a point of reference, readers should keep in mind that every situation is different and that flexibility and adaptability are invaluable skills for lawyers.

Penick and Black's survey of offshore issues describes the key features of an offshore legal regime that has taken nearly two decades to develop; predictably, given the multitude of resource uses to which the offshore is subject, environmental regulation continues to occupy a key place. They point to the importance of compliance with relevant environmental impact assessment requirements, especially in light of the current uncertainty about the applicability of federal laws in this regard. The Oldman case, referred to in the Leew and Thackray paper as on appeal to the Supreme Court of Canada, may help to relieve some of this uncertainty. Penick and Black have provided a detailed outline of the laws that currently apply in the offshore areas; this elucidation of a complex system will be helpful to solicitors advising clients on matters of financial security relative to offshore projects.

Brett's paper on cogeneration provides an overview of legal and related issues that are resulting from the use of a new form of energy generation. Environmental concerns make it likely that there will be increasing pressure to employ alternatives that are more benign

Dean and Professor of Law, University of Calgary. Since this commentary was written, the author was appointed as a Justice of the Court of Queen's Bench of Alberta. 
than the burning of hydrocarbons; of these, cogeneration may be the most promising from the point of view of the petroleum industry. In addition to reviewing the types of contracts that are required in order to make cogeneration projects work (some of which will be familiar to readers), Brett's paper underscores important questions about the policy role that governments can and should play in fostering the development of alternative energy forms. He compares some of the initiatives that have been taken in this regard in Ontario and British Columbia with those in the United States, and outlines the tax incentives available in Canada to foster cogeneration projects. In regard to the latter, it is worth noting that there is growing interest in the use of financial incentives as a technique of environmental improvement and this trend is likely to raise interesting new legal issues in the future.

A number of similar issues underlie Lehodey and Pelzer's examination of the legal implications of horizontal drilling. This relatively new technology, while costly, is arguably an improvement over conventional drilling in that it causes less surface damage and results in a higher degree of production from reserves. Here, too, lawyers are being called upon to adapt existing contractual forms (such as freehold leases and operating agreements) to respond to new problems. Lehodey and Pelzer's comparison of the regulatory response to this technology in the adjacent producing provinces of Saskatchewan and Alberta points out the challenge that faces policy-makers in reacting to such developments in the industry and again raises questions about the appropriate role of government and regulators in such situations.

Despite the fact that we are supposedly in an era of "de-"regulation, a number of the papers illustrate that such goals have been proven difficult, if not impossible, to achieve. Most telling in this regard is the Yates/Keeley exposé of the context which surrounds exports of Alberta gas. Their clear explanation of current forces will help to bring readers up to date on this complex and constantly-changing area. The Canada-United States Free Trade Agreement, as they point out, plays a role in this regard and, it may be asserted, has made matters more rather than less complicated. Arguably, it is becoming increasingly important for Canadian lawyers to understand something about American law, a point that is emphasized by their discussion of the possible implications of American anti-trust law for activities that occur in Canada. Sheppard's paper on Investment Canada indicates the fact that, although the rules have changed to a considerable degree, there are still a myriad of investment laws and policies about which lawyers ought to have a working knowledge. The many regulatory developments discussed in the DiSanto/Ferguson/Forrest paper also indicate the constant force that regulation exerts upon the industry.

Living as we do in a federal state, constitutional issues continue to provide an important backdrop for any discussion of oil and gas matters. The offshore regime described by Penick and Black has emerged from an era of federal-provincial cooperation; but there are many examples of the fact that constitutional issues lurk constantly in the background, in part because of the fact that they can be, and often are, raised by third parties. Yates and Keeley, for example, consider the possible grounds for constitutional challenge of the California Public Utilities Commission's actions and of Alberta legislation. The Northern Badger case, referred to in the Leew/Thackray paper, 
reveals how environmental activism at the provincial level (in that case, actions taken by the Alberta Energy Resources Conservation Board to come to grips with the problem of "orphan wells") can run afoul of the division of legislative authority provided for in the Constitution (notably, federal authority over bankruptcy).' The case points to the fact that, whether or not we are in a period of federal-provincial co-operation, there is an ongoing need for co-ordination between the two levels of government if both are to achieve important policy objectives.

Another example of the importance of constitutional law is the Ellis-Don case, which is also discussed by Leew and Thackray. This case raises questions about the viability of the due diligence defence in the face of the presumption of innocence contained in the Charter of Rights and Freedoms. Although Ellis-Don was not concerned with the use of this defence in an environmental prosecution, the principle which it raises may be applicable in that context, as well. If the Ontario Court of Appeal's view is upheld in the Supreme Court of Canada, a re-examination of the basis of much of our current environmental regulatory system could be necessitated. ${ }^{2}$

There are several indicators of the growing role being played by aboriginal people in Canada. For example, DiSanto, Ferguson and Forrest set out some details concerning recent Metis land settlement legislation in Alberta; discuss the National Energy Board's decision GH-10-88 in which the Dene-Metis Negotiations Secretariat played a major part. They also explain the implications of a decision taken by the Environmental Impact Review Board (established under the Inuvialuit Final Agreement) in regard to Gulf's proposed drilling program in the Beaufort Sea. The announcement of the establishment of a Royal Commission on aboriginal issues, in concert with the prominence that is being attached to the aboriginal viewpoint in emerging recommendations about Canada's constitutional future (by, for example, the Spicer Commission and the Group of 22), suggest that this is a trend that is likely to continue.

A myriad of private law issues, of course, continue to challenge petroleum lawyers. Many of these are outlined in Leew and Thackray's discussion of recent judicial developments. Smith and Denstedt provide an explanation of issues surrounding the socalled pre-emptive rights frequently found in industry contracts; these have taken on increasing importance at a time when the sale and purchase of oil and gas properties are rampant. MacLean's examination of key changes found in the 1990 CAPL Operating Procedure will be an invaluable source of information for readers; the overall influence of the CAPL Operating Procedure is reflected in a number of other papers, including those by Smith/Denstedt, Leew/Thackray and Lehodey/Pelzer.

Since this commentary was written, the Alberta Court of Appeal has upheld the validity of the ERCB actions, inter alia because it saw no direct conflict between the relevant provincial legislation and the Bankruptcy Acr; (1991), 81 D.L.R. (4th) 280. Leave to appeal to the Supreme Court of Canada has been sought.

2. Since this commentary was written, the Supreme Court of Canada has upheld the due diligence defence in another case. See $R$. v. Wholesale Travel Group Inc., [1991] S.C.J. No. 79. 